\title{
7 Waiting out the condition of illegality in Norway
}

\author{
Marry-Anne Karlsen
}

\section{Introduction}

'I give it one more year,' Aziza ${ }^{1}$ said resolutely. 'If nothing changes, I'll go to the police and tell them they can send me wherever they want to. I don't care.' We were just leaving Stella, the Red Cross Women's Centre in Oslo where we had met for a coffee and a catching up chat a cold November day in 2012. Aziza had applied for asylum 4 years earlier and had remained when her application was denied. The week before our coffee chat, Aziza had been notified by the Directorate of Immigration that she would be formally expelled with a 5-year re-entry ban due to violation of the immigration regulations. When I had met her briefly a couple of days earlier, Aziza having just received the letter was shocked, not knowing what to do. To Aziza, the expulsion letter was not only a severe setback to her hopes of regularisation but also to her attempts to expand her family. During her time in Norway, Aziza, who was in her late 30s, had married and they were trying to have a child. Although her husband had permanent residency in Norway, their religious marriage was not recognised by the Norwegian state due to her lack of legal status.

This was not the first time Aziza had mentioned her plan of giving it one more year. Exactly what she would do in a year's time was unclear. She could try to apply for asylum in another European country but knew this would probably be futile due to what she called 'the fingerprint system,' that is the Dublin agreement. This is an agreement that determines which European country is responsible for processing an asylum application. If returned to Ethiopia where she was born, she could perhaps apply for family reunification, she mused. However, the 5-year re-entry ban complicated this. Could she ask her husband to wait that long? Aziza realised that her plans had problems. As she put it, 'I know that it's veeery hard. But I don't have any options at this stage. Because if you are living illegally, the more you stay illegally, the more you become illegal. This stresses me even more.' However, when I returned to Oslo in the autumn of 2017 for a new period of fieldwork, Aziza was still living in Norway - illegally.

The presence of irregular migrants such as Aziza, who remain for years despite harsh living conditions and formal membership being denied, 
remains a conundrum for policy-makers in many destination countries, including Norway (Van Houte \& Leerkes, 2019). Since 2004, Norway has increasingly limited irregular migrants' access to welfare services and work, making the living situation for irregular migrants more precarious (Karlsen, forthcoming). These restrictive policies are largely informed by an assumption that the lack of such benefits and opportunities will form a disincentive to coming or remaining in the country illegally. As such, they rest on a rational choice model of human agency, seeing migrants as strategic agents whose decisions are driven by basic calculations of push and pull factors. This model has, for good reasons, been criticised for being overly simplistic, and for putting too little emphasis on the ways in which migrants act within complex social relationships (Carling \& Collins, 2018).

In this chapter, I will explore what it means to endure or 'wait out' the condition of illegality in Norway. Illegality is here understood as a historically specific, socially, politically and legally produced condition (De Genova, 2002), which profoundly affects migrants' social relations as well as mode of being in the world (Willen, 2007). Scholars have particularly highlighted how the persistent possibility of deportation shape existence under this condition, rendering life both more unpredictable and exploitable (De Genova, 2002; Machinya, 2020).

The notion of endurance or 'waiting out' can be understood as a particular way of inhabiting the temporal category of waiting. One waits to see what happens or for something bad to end, rather than waiting in anticipation of a specific future event (Hage, 2009). The emphasis is on living through the present conditions. Scholars have importantly drawn attention to the ambivalent nature of endurance. It can be approached both as a governmental tool that encourages self-control in times of prolonged crisis and as affects and practices that allow people to persevere under unfavourable conditions. Through these practices and affects new forms of life can emerge (Povinelli, 2011). It is this ambivalence between subjugation and potentiality, I suggest, that makes endurance a productive lens for analysing people's attachments to an undesirable present. Exploring this ambivalence, I will in the following examine the social, affective and temporal dynamics of 'waiting out' illegality in Norway. What practices and affects of endurance emerged under this condition? How did 'waiting out' work as a mode of governing? I will also unpack how this mode of waiting was entangled with a sense of spatio-temporal entrapment and the more hopeful form of 'waiting for.'

\section{Fieldwork}

The chapter builds on two extended periods of ethnographic fieldwork. The first was conducted at various lengths and intensities between October 2011 and October 2013 in Bergen and Oslo, the two largest cities in Norway, as part of an interdisciplinary project on the provision of welfare to irregular migrants. The second consisted of 5 months of intensive fieldwork in 
Oslo in the autumn of 2017, as part of a larger project on the temporalities of irregular migration. Contact with irregularised migrants were made in various ways during both fieldwork periods: Through the healthcare centre for undocumented migrants in Oslo, through non-governmental organisations (NGOs) and activists, gatekeepers in ethnic communities and at public events organised for and by irregular migrants. During the fieldwork in 2017, I also spent time with an organisation called People in Limbo (Mennesker $i$ Limbo). This was an organisation for and by 'long-staying undocumented migrants, ${ }^{, 2}$ which organised a mixture of political and social activities. The organisation was initiated in Oslo in 2016 with the support of the healthcare centre for undocumented migrants and the Church Outreach mission. Branches have since been established in several cities in Norway.

My analysis in this chapter draws specifically on my encounters with women from East Africa and the Middle East, who had stayed between 5 and 20 years in Norway after their application for asylum was rejected. In the Norwegian public debate, rejected asylum seekers who remain for years without state authorisation are often labelled, and label themselves, as 'long-staying' (lengevarende) asylum seekers/undocumented migrants or 'unreturnable' (ureturnerbare). Norwegian Association for Asylum Seekers (NOAS) defines children who have stayed in Norway for more than 3 years and adults who have stayed for more than 5 years as 'long-stayers.' 'Unreturnable' refers generally to people who are difficult to deport, either due to lack of identity papers, lack of return agreements or political reluctance and unstable conditions in their countries of origin. Although the term has gained some acceptance politically, and within the bureaucracy (e.g. the Granavolden platform ${ }^{4}$ ), the position of Norwegian authorities has mainly been that no one is 'unreturnable'; there are only 'return refusers' (returnektere) (Lønseth, 2011). A key issue at stake in these different labels is who is to be held morally responsible for the current impasse - the migrants themselves or the state that fails to deport them (Karlsen, 2017).

Not all my interlocutors were difficult to deport. State efforts to secure new return agreements importantly changed the situations for some over time. For example, rejected asylum seekers from Ethiopia constituted one of the main groups of those considered 'unreturnable' during my first period of fieldwork. However, changes in the return agreement in 2017 and 2019 made it easier for the state to carry out deportation to Ethiopia. In the following, I will refer to my interlocutors as 'long-stayers' due to the temporal focus of this chapter but also because of this label's centrality to how my interlocutors conceived of themselves.

\section{Spatio-temporal entrapment}

Endurance generally emerges in situations where someone else is calling the shots, or when something compels one to stay on and keep trying (Frosh, 2015). As such, it can appear to be a default outcome or response to what 
Hage (2009) has conceptualised as 'stuckedness' or existential immobility. Based on his work among Lebanese migrants and white racists in Australia, Hage (2009) suggests that some form of imaginary mobility, a sense that one is going somewhere in one's life, is essential for a liveable life. 'Stuckedness' thus refers to a specific form of waiting that emphasises a limit to futureoriented actions (Straughan et al., 2020). Scholars observing an increasing disconnect between conditions and aspirations presented by contemporary capitalism in a variety of contexts have further suggested that migration is increasingly positioned as a spatial answer to an inability to experience progress in time (Ferguson, 2006; Mains, 2007). However, as migration control intensifies, leading to fewer legal possibilities for settlement and increasing the cost of renewed mobility, migration may be the cause of renewed stuckedness in destination countries (Pettit \& Ruijtenberg, 2019). I suggest that to understand how endurance emerged among my interlocutors as a way of orienting oneself temporally, it is necessary to appreciate how the condition of illegality was experienced as a form of spatio-temporal entrapment.

Reflections on stuckedness were recurrent throughout my interactions and conversations with various long-stayers in Norway. As Aziza, for example, would put it when we discussed her situation in 2017: 'The years are running, but you are in the same place. You don't study. You don't work.' Overall, she and my other interlocutors tended to foreground a sense of waiting that was all encompassing and disempowering, but which also reflected a normative valuation of a linear and progressive forward movement in time as a condition for 'good lives.' This points to how the sense of 'stuckedness' reflect specific temporal norms regarding what makes life meaningful and valuable.

Scholars of social time relate a future-oriented temporality to the institutionalisation of chronological time, and the onset and global spread of capitalist modernity (Adam, 2003; Jeffrey, 2010). This, they suggest, has provided powerful temporal templates for how social lives should be mapped onto abstract units of time such as days, weeks, months, years and decades. The notion of life course provides, for example, not only gendered expectations about when and in what sequence in one's life course one should study, work, marry, etc., it also produces measures from which one can evaluate one's progression and productivity. Linear time and the associated notion of progress and productivity that ascribes monetary value to time further produces a temporal hierarchy that distinguishes between those who are investing time/losing time or spending meaningful time/empty time (Lahad, 2017). In this context, waiting carries pejorative connotations, and is associated with wasted time and wasted lives. Scholars have noted how modern temporal templates continue to have normative force even though neoliberal policies and increased precarisation of work life have eroded the possibilities for progressive linear life courses for an increasing number of people all over the world (Kleist \& Jansen, 2016). This may be particularly so when one owns existential immobility is contrasted to others who are still seen to move ahead in a linear progressive fashion (Lahad, 2017). 
A central challenge for Aziza and other living in a condition of illegality in Norway was that there was no obvious pathway to regularisation, nor a spatial way out of their current impasse. The sense of not being able to move forward in life was thus closely connected to a sense of spatial entrapment. As Aziza put it in the same conversation:

It is very difficult to keep waiting. But we have no choice. Some people try to go other places. But there is the problem, you know, with fingerprints. They try to go somewhere else, and they are still in the same situation [i.e. without legal status].

Similarly, Adila, an elderly woman from the Middle East and one of my regular interlocutors during my fieldwork in 2017, would whenever I met her start exclaiming 'where to go, where to go?' I learned quickly that it was not a question she expected me to answer, but a way of expressing the pervasiveness of the spatial and temporal entrapment she experienced and the ways it provoked distress. The question was the one she was thinking about 'all the time,' 'every day and night.'

Adila had at one time tried to go to Sweden but had been deported back to Norway under the Dublin regulation. Adila was not the only long-stayer whom I met who had tried to go to another European country. While some would continue to move between different European countries, others had, like Aziza, contemplated re-migrating at an early stage, but had over the years abandoned such plans as they learned of the challenges others had faced. My interlocutors did not conceive of return to their country of origin as a viable option, and expressed many different and individual mixtures of reasons for why return was experienced as impossible. Some maintained strongly that a return would be dangerous; others had families, including children with Norwegian citizenship that they did not want to leave behind. Others again had applied and been denied assisted return with the International Organisation for Migration (IOM). ${ }^{5}$ Additionally, the investment and risk they had taken to migrate, and the years spent waiting, made contemplating return even more difficult. As Aziza explained it: 'We don't have any future. Because we are not developing, we are not learning. And even if you go back to your country after 20 years, you will need everything. Your age, your ability to work, everything has changed. Even the culture isn't yours anymore. It's not so easy.'

In addition to being stuck, limbo, imprisonment and entrapment were metaphors used by my interlocutors to articulate an experience of waiting as imposed spatial and temporal immobility. ${ }^{6}$ The sense of entrapment was also conveyed in the logo of the organisation: People in Limbo. When I started my fieldwork in 2017, they used as logo an image of people trapped in a bottle, with the bottleneck being marked with one-way street signs indicating one could go in, but not out. Worried that the image of the bottle could be misunderstood as referring to alcoholism, they changed it to an image of a crouched person inside a locked padlock. 


\section{Waiting for and waiting out}

So, how does one, in such situations when spatial mobility no longer represents a way out of stuckedness, plot a movement from the present to an imagined and desired future? Is it at all possible? Within anthropology, the concept of social navigation has gained traction as a tool to address how people act in difficult or uncertain circumstances. Social navigation encompasses, according to Vigh, "both the assessment of the dangers and possibilities of one's present position as well as the process of plotting and attempting to actualise routes into an uncertain and changeable future.' The concept of navigation thus designates a 'movement through both the socially immediate and the socially imagined' (Vigh, 2009: p. 425). However, stressing how social navigation is always contingent on power relations, Ramsay contends that not all situations are navigable. Non-navigable situations are those, she argues, where "the possibility of a self-directed future is constrained by external forces' (Ramsay, 2019: p. 4). The condition of migrant illegality can be conceptualised as such a non-navigable situation, where the future is not only uncertain, but is determined by forces that are outside of one's direct control. Yet, endurance or 'waiting out the crisis' could also be conceptualised as a form of 'social navigation,' where the emphasis is on living through the present conditions rather than moving forward.

My material indicates, however, that 'waiting for' and 'waiting out' are not necessarily a simple binary but a constant and often simultaneous orientation. My interlocutors would, for example, respond differently in the same conversation to questions regarding the future depending on how I framed the questions. If I asked how they saw their future, the most common answer was that the future was 'black,' indicating an enforced presentism in which it was impossible to envision a future. As Nala, a woman in her twenties from Ethiopia put it: 'When you have things in place you can think about the future. Right here and now, when you have nothing, you can't think of the future.' Aziza also stressed that thinking about the future made her sick. Headaches, stress, sleeplessness and depression, health problems that were largely attributed to their difficult life situation were common among my interlocutors.

When I asked my interlocutors what they would do if they got residency, they would often elaborate quite detailed plans or desires (what they would like to study or the type of work they wanted, even where in the city they would like to live), thus expressing a clear vision of how they hoped a future life in Norway would be. This difference, I suggest, highlights the tension between desired futures and present possibilities of realising it but also how waiting in the context of migrant illegality in Norway is ambiguous in its relation to the present and the future. For while the future was unimaginable, the present was made uninhabitable by the intensification of exclusionary practices towards irregularised migrants (Karlsen, forthcoming). For my interlocutors there was thus a constant oscillation, or even blurriness, between 
waiting for regularisation or deportation and waiting out the condition of illegality. This included a continuous engagement and disengagement with the system of applying for asylum, between trying to find a way to live with the present and trying to realise the desired future by becoming regularised.

In the Norwegian system, the UDI (Directorate of Immigration) makes the initial decision in asylum cases. In case the UDI rejects an application, it can be appealed to the independent Immigration Appeals Board (UNE). If UNE rejects the appeal, it is referred to as 'the final decision.' If the rejected asylum seeker does not leave before the departure date set for him/ her, his/her stay is generally no longer considered legal. However, rejected asylum seekers can continue to request a reversal ('omgjøringsbegjaring') from UNE. To reverse the decision, UNE requires new pertinent information or new documentation regarding one's case, or that one's situation has changed significantly (e.g. that you have become seriously ill). However, the threshold for UNE to reverse a case is high. Length of time in Norway is on the balance counted negatively. There is also the option to bring the case before the courts. This can be both a lengthy process and quite costly as one would have to pay for the lawyer and risk being accountable for the state's costs. A few organisations provide free legal aid, most importantly NOAS.

All my long-staying interlocutors had requested a reversal more than twice, sometimes with the assistance of NOAS, by hiring a private lawyer, or simply writing a letter on their own. Some of my interlocutors seemed relentless in their determination to retry their cases, starting preparation (gathering documents, saving money for lawyers) for a new appeal or a court case as soon as they received the rejection. Others expressed resignation and lack of faith in the system but would still apply at times. For all, appealing marked a renewed intensity of waiting, producing both heightened anticipation and hope, but also stress, anxiety and fear, before yet another crushing disappointment. As Liya, who had stayed for more than 10 years and applied several times, put it when I asked if she would try again, 'I go crazy if I get one more rejection!' So, why do rejected asylum seekers continue to appeal their case?

\section{Technologies of patience}

'The government gives us two and a half options,' Aziza explained to me one autumn day in 2017 while we were walking towards the mosque so she could pray. Aziza had just been to see her lawyer to discuss the possibility of bringing her case to the court, but they had decided it was 'not the right time.' In her words, the first option was to be sent out of Norway to an unknown fate. The other was 'a bit of bread and a place to stay.' The latter was a reference to the government's offer to accommodate rejected asylum seekers in asylum reception centres. ${ }^{7}$ According to Aziza, most people choose this option. The half option, she explained, was the hope that the politics 
would change so that they could stay. 'Together, the second and the half option destroy people's life,' she concluded.

A few weeks later, sitting in a café at the Oslo Central Station, I prodded Aziza further on what waiting meant to her. I had heard her previously joking with a friend in a similar situation about how they were 'learning to wait' in Norway. I asked whether she had experienced the same sense of waiting during the 10 years she worked and lived without a legal status in the Middle East, before coming to Norway. 'It was worse there,' she started explaining 'physically.' She described how she could not talk or move around freely, how she was at the mercy of her employers. In Norway, though, it was not physical hardship and constraints, but 'mental torture' that was the main challenge. 'There you knew already that you didn't have any rights. But you had a plan,' she explained further. 'You still had hope that you could leave the country. But this [Norway] is a democratic country. You don't want to leave without hope.' In the end, she concluded: 'You know why we are waiting here so long? Because we know this is a democratic country. Tomorrow something can happen.'

Hernandez-Carretero (2016), in her study of Senegalese migration to Spain, found that the interplay between hope and uncertainty affected migrants' willingness to take chances. While her interlocutors communicated a sense of positive anticipation when recounting their initial decision to migrate, they stressed concerns about preparedness, failure and shame when discussing return. Hernandez-Carretero thus suggests that the contrast in migrants' attitudes to uncertainties upon emigration and return lies in hope's power to mediate uncertainty. Aziza's response to my questions resonates to some extent with this point, but her answers also draw attention to the enduring affective power of the liberal societies' promise of future possibilities and progress. Waiting for regularisation or 'politics to change' names in this sense a cruel attachment to a compromised condition of possibility (Berlant, 2011: p. 24).

Cruel optimism is, according to Lauren Berlant (2011: p. 28), a technology of patience that enables a concept of the later to suspend questions about the cruelty of the now. The concept allowed Berlant to explain how liberal societies maintain their legitimacy despite the capitalist destruction of life. What makes an optimistic attachment cruel, according to Berlant, is not only that the object of desire is itself a threat to one's well-being, but that 'its life-organizing status can trump interfering with the damage it provokes' (Berlant, 2011: p. 227). Hence, for people who lack control over the material conditions of their lives, the fantasy of the normative good life may be what makes life bearable.

In the context of migrant illegality, the concept of cruel optimism provides a vantage point for inspecting migrants' continuing affective investment in the promise of asylum and citizenship, despite the fact that the nation-state system actually produces their illegality. Waiting for regularisation can, for example, work as a technique of governing by temporally 'bracketing' 
present harm through the promise of a future residency permit, as argued by Drangsland (2019). Analysing an offer of possible regularisation that the Hamburg Government presented to a group of 350 West-African migrants in 2013, she showed how the offer made waiting appear as a redemptive state. In the case of my interlocutors, the redemptive promise of future residency was more ambiguous as there was no specific offer of regularisation. Although the asylum system continued importantly to shape their future horizon, I suggest that it was a combination of 'waiting for' and 'waiting out' that together formed a continuing imperative to stay. As technologies of patience, they differ slightly from each other.

Unlike the German Government, which has opened various pathways to regularisation for tolerated migrants due to criteria of economic selfsufficiency and language skills (Drangsland, 2020), shifting Norwegian governments have insisted that 'return,' assisted or forced, should be the primary pathway out of illegality. Norway's deportation rates have, in consequence, been among the highest in Europe (Van Houte \& Leerkes, 2019). Yet, despite a political consensus concerning this exclusionary approach, smaller humanitarian mechanisms and programs have been implemented in response to public concern, primarily regarding so-called long-staying asylum children. ${ }^{8}$ For adults there were, as already mentioned, the continuous possibility to request a reversal from the appeal board (UNE) or to take the case to court. Even though only few cases are reversed, such exceptions continue to foster a certain hope of regularisation despite this not being a reliable pathway for most. To paraphrase Povinelli (2011: p. 190), the 'incitement to wait, to be patient, to bracket harm until the impasse has been resolved' was still key to how power worked in this case. Among my interlocutors, there were different ways of making sense of the system. One way was to see it as an unpredictable lottery. While this fed into a sense of unfairness, it still incited people to keep trying. The other way emphasised the need to work hard on your case, gathering the right documents and contacts. In either case, the continued promise of regularisation as the route to 'the good life' served to individualise and internalise a mode of governing the self into waiting orderly. The continuous engagement with the system required significant investment in terms of affect but also time and money. It also continued to re-affirm the authority of the state to decide on their status.

'Waiting out' as a mode of governing the self, works by valorising the ability to suffer and yet persist. With reference to neoliberal Australia, Hage (2009) suggests that a particular celebration of the heroism of being stuck has given rise to a deeper form of governmentality, in which a capacity to stick it out and 'get stuck well' becomes a marker of good citizenship. This is, for example, seen, he suggests, in the vilification of those who do not wait well, such as the 'queue jumping' irregular migrant.

Various scholars have noted how irregular migrants in their regularisation efforts have drawn on notions of good citizenship to claim belonging (Anderson et al., 2011, Bendixsen, 2013). However, there is generally little 
heroism associated with waiting out the condition of illegality. In some countries, social participation over time can create grounds for legalisation as proof of attachment and deservingness (Chauvin \& Garcés-Mascareñas, 2012). Yet, in most cases it simply works to document lengthy breach of immigration law, thus making it a more serious offence in the view of the immigration authorities. As Aziza put it earlier: 'If you are living illegally, the more you stay illegally, the more you become illegal.' Still, I suggest that endurance even in the context of migrant illegality denotes a mode of governing the self through its emphasis on coping under, rather than changing, the existing order. It is to the ambivalence between subjugation and potentiality in 'waiting out' that I will turn to now.

\section{Surviving in the impasse of the present}

In sporadic conversations over the years, I had noticed how Aziza's determination to leave after a year kept being postponed until it completely faded. Instead, she started increasingly to bring up in our conversations how she tried to learn to be content with what she had, and not stress too much about her lack of legal status and what would happen in the future. As she put it in a conversation in 2017: 'Me and my husband have discussed it, and lately we have decided that we could live like this, even though I don't get residency.' Another time she elaborated:

I'm lucky. I have a husband. I know where I live, even though I can't contribute economically. (...) If I cannot do anything with my legal situation, I must accept these things. I cannot study, I cannot work, I cannot travel, but I must accept what I have in my hands now. That is why I try every day to be active.

Aziza and her husband had not been able to have a child, but after years of economic difficulties, her husband had obtained stable and decent employment and they had been able to move into a larger and nicer apartment. Aziza who could not work legally, had involved herself in diverse forms of volunteer work as a way of keeping herself active.

Aziza did not completely abandon attempts to get regularised, but there was, as the quotes indicate, a slight shift of emphasis towards finding ways to endure. She was not alone in this reorientation. During my time in the field, I observed the emergence of a determined effort among my interlocutors and their supporters to find ways and techniques to cope with the insecurity and stress of being an irregularised migrant, to find meaning in their present lives even if they could not get regularised. In 2012, when I first started doing fieldwork in Oslo, the volunteer-run healthcare centre for undocumented migrants had operated for 2 years. One of the central challenges they experienced when providing healthcare to this group was that the cause and cure for the patients' ill health was not necessarily found within the traditional 
biomedical perspective (Karlsen, forthcoming; Ottesen et al., 2015). For example, a certain level of stability is usually understood as a professional and ethical requirement for initiating trauma treatment. However, this stability is difficult to achieve when faced with irregular migrants whose continuous life crisis is a consequence of a deliberate policy of exclusion.

In the period from 2011 to 2014, the healthcare centre initiated a pilot project with group consultations that attempted to develop appropriate techniques for the stabilisation of trauma symptoms and the management of daily stress for their patient group (Mburu et al., 2015). As part of their psychosocial strategy, the centre also started facilitating venues for socialising and mutual support, and offered some of their regular patients the opportunity to work as volunteers at the healthcare centre, either as community workers who would welcome and provide newcomers with information while they were waiting for their appointment, or by making food to the volunteer healthcare providers. They also reached out to other organisations to facilitate more opportunities for volunteer work.

The aim of these initiatives was to create meaningful and routine activities as a tool for irregular migrants to deal with the daily stress of illegality. In this sense, they were designed to address what was seen as the challenge of an excess of time. By being formally excluded from institutions such as work and education, the condition of illegality was often experienced as a form of enforced idleness. As Janet, a Ugandan woman who had lived in Norway for 10 years, expressed it, 'After all I've been through, waiting here is the hardest thing. For me, a hard-working girl, I never sat still in my life.' Awate, originally from Eritrea, made similar remarks, 'We are not beggars. (...) If we are not sick, we work. Hard work is in our culture.' Scholars have pointed out that such statements must not be understood just as conveying an aspect of their identities but also as challenging the discursively and institutionally produced positionality of the 'unproductive Other' (Haas, 2012: p. 253, Bendixsen, 2013). As normative judgments are attached to how people spend their time, the challenge of too much time was not only that it made it difficult to escape pervasive and distressful thoughts, but that it was also in itself felt as a source of shame. This points to how a temporal hierarchy of moral worth, in which unequal relationships to time signal differences in status and privilege (Sharma, 2014), is internalised. When time becomes a question of vice (wasting time, passivity) or virtue (patience, keeping active), waiting becomes an action that may be done well or badly.

The healthcare centre's initiatives to create regular activities resemble what Feldman (2015) describes as humanitarian 'endurance projects.' Working in Palestinian refugee camps, she uses the term to describe a range of interventions that were aimed at helping people in the camps live better with circumstances they cannot change. These projects, she argues, make the claim that there is value to Palestinian lives even if they can never be improved. This claim, however, made such projects in part contentious, as they do not 'challenge the deep inequality of lives' (Feldman, 2015: p. 430). 
They do not resolve the fundamental problem, but 'put the question of how to live a better way, even when one cannot live a better life, at the core of their concerns' (Feldman, 2015: p. 431). According to Feldman, endurance projects are dogged by a sense of failure: 'The very fact that endurance may be the only option available to people indicates a failure of other (more active, more strategic, even more revolutionary) pathways' (Feldman, 2015: p. 435).

In my field, the various initiatives of the healthcare centre seemed to have had a clear positive impact on my interlocutors who had been involved. In addition to how the activities served to distract them from their problems, Aziza and others who volunteered emphasised that they experienced increased self-worth. Yet, as endurance projects, they kept being dogged by the future horizon being restricted. While the initiatives served to organise and regulate thoughts and activities, they did not necessarily create a temporal horizon that would give the wait meaning. Aziza would, for example, continue intermittently to express a sense of overwhelming stuckedness, as in this quote from the same conversation in 2017, in which she expressed a determination to focus on what she 'had in her hands now'; 'I cannot do anything for myself. Of course, I can do something, so I don't feel stressed. I can do voluntary work with different organisations. These things help me. But you do not know what is happening tomorrow.' Later she added, 'You always think: What happens tomorrow? What can I do for the future?' This suggests that, as argued by Brux et al. (2019: p. 1454), it is not necessarily enough to participate in a socially validated, chronological and sequential everyday time without the ability to emplot this and render it meaningful within a comprehensible biographical and social narrative.

Aziza's resolution to focus on the positive sides of her life, of her present, would also frequently be derailed, such as when she learned that someone she knew had been deported to Ethiopia. 'I have my suitcases ready,' she told me shortly after the deportation of her acquaintance. 'Well, they are not exactly packed,' she corrected, 'but I have made a mental plan and have sorted my things, so that I can easily put them in my suitcases if they come for me.' The endurance projects were as such also dogged by the government's policy of actively making the present uninhabitable for irregular migrants, both through the 'spectacle of deportation' (De Genova, 2013; Machinya, 2020), and by restricting access to healthcare and work.

The latter was something People in Limbo tried to address at different levels. While the healthcare centre's psychosocial initiatives were mainly individual endurance projects, People in Limbo engaged in what can be described as a more collective endurance project. Regularisation remained a key objective for the organisation, but most of their political efforts were directed at the right to healthcare and the right to work without legal status. This was mainly a strategic decision, as these claims were seen as more feasible in the Norwegian political climate. The decision was also related to the significant experience of some of their members, including Liya, that 
the uncertainty regarding the possibility to remain was increasingly intertwined with an uncertainty regarding the possibility of gaining access to material resources, such as food, housing and medical services.

Liya was one of several rejected asylum seekers who previously had regular and stable employment of which they paid tax. In 2000, the Immigration Act and associated regulations explicitly allowed rejected asylum seekers to be granted temporary work permits until deportation or assisted return could be effectuated. The practice of granting work permits was cancelled through a circular issued by the directorate of immigration in 2003. Tax cards were, however, issued automatically to previous tax cardholders until 2010, when a clean-up in the tax administration put a stop to the practice. The change in work permit policy and practice was part of the larger attempted clampdown on irregular migration. While there is little indication that this policy change had the intended effect, it clearly aggravated the situation for people like Liya, making their lives more precarious. Many found it difficult to find work without a tax card and were largely left to rely on help from friends or family or move back into the asylum reception centre.

People in Limbo's efforts went beyond simply campaigning politically for the right to work. Two of the main activities carried out during their weekly meetings consisted in making a sort of identity cards for new members and registering them for a staffing agency for rejected asylum seekers. PLOG AS, the staffing agency, was initiated by the Norwegian Arne Viste in 2015. Viste's aim was to be prosecuted so he could test whether denying rejected asylum seekers work permits contradicted the Norwegian constitution. PLOG would collect fees from companies that used the employees' services and pay salaries to the workers after withholding tax duties, as required under Norwegian law. The aim of this mechanism was to shield both the companies PLOG cooperated with and the migrants they employed from legal repercussions. Everything though was done openly and PLOG would regularly update authorities and report the activities to the police. As the police was reluctant to prosecute, PLOG kept challenging bureaucratic structures that ignored the existence of rejected asylum seekers by consistently trying to pay taxes.

Between 2015 and 2019, PLOG issued approximately 700 'work permits,' referring to the Norwegian Constitution and the Human Rights Act. ${ }^{9}$ Rejected asylum seekers were encouraged to bring this 'permit' to the places they were seeking work. While the 'work permits' had no legal validity, the arrangement PLOG offered encouraged some employers, who would not otherwise have done so, to hire rejected asylum seekers. In other cases, it helped workers who were already employed informally to negotiate more stable work arrangements and better pay. A total of 70 migrants were at one point hired through PLOG. For some, it amounted to stable employment over time. For others, the work was only a few hours for a short period. Yet, the work represented a value that went beyond the economic gain. For example, I asked Liya whether the few hours she was employed through 
PLOG were worth it. Rather than emphasising the economic side of it, she answered: 'At least it is a few hours I don't sit at home watching films.' Others expressed that it gave them a sense of dignity.

Beyond the individual level, the initiative gave People in Limbo a collective purpose. People who were not necessarily employed through the agency provided support by recruiting and registering potential workers. While Viste's pursuit of a court case produced a sense of movement and hope for change, the more mundane activities People in Limbo and PLOG engaged in gave a sense of purpose in the present. Moreover, the activities afforded to some extent, I suggest, the opportunity to build networks and exist in ways different from those prescribed by the state. 'Waiting out' or enduring the condition of illegality could in this sense be seen as a refusal to accept state power to categorise people and circumscribe their lives.

\section{Concluding remarks: subjugation and potentiality}

I started the chapter by noting how the ambivalence between subjugation and potentiality makes endurance a productive lens to analyse why irregularised migrants remain, even when faced with exclusion, hardship and suffering. How can we appreciate the potentiality of such alternatives in a condition framed as futureless by the political regime? To Povinelli (2011), endurance makes a difference even if it does not immediately produce social transformation as it allows people to be something else than simply defeated by the circumstances. To avoid romanticising forms of suffering, scholars have also stressed the need to be clear about the tenuous and contingent conditions of these alternatives when exploring the potentiality of endurance (Neale, 2012; Wool, 2017). Without problematising the broader systems in which some groups must endure while others prosper, a turn to endurance may serve to normalise adaption to unfavourable conditions and foreclosing wider socio-political questions of power and representation (Feldman, 2015). Endurance risks simply becoming a gradual slow wearing out.

Among the long-staying rejected asylum seekers in my study, endurance emerged in relation to an overwhelming sense of spatio-temporal entrapment. Both future-oriented actions and spatial mobility were experienced as severely circumscribed. 'Social navigation' thus became increasingly about living through the present conditions, or 'waiting out the crisis.' The individual and collective endurance projects that emerged in this context to assist long-stayers to find better ways to live or to cope in the present certainly contributed to making irregularised life more bearable. Also, a form of lived alternative sociality emerged to some extent through the practices aimed at waiting better. Yet, they remained somewhat dogged by the lack of a future horizon. The opposite of endurance, exhaustion, was thus never far away.

In the context of migrant illegality in Norway, the asylum system continued importantly to shape rejected asylum seekers' future horizon even after the so-called final rejection. I therefore suggest that it was a combination of 
'waiting for' and 'waiting out' that together formed a continuing imperative to stay. As technologies of patience, they work slightly different. In addition to 'bracketing' present harm through the promise of a redemptive future (Drangsland, 2019), 'waiting for' relies on a certain sense that the 'queue' one is in, is actually moving, even if it is infinitely slow (Hage, 2009). 'Waiting out,' in contrast, invites self-control through internalising a temporal hierarchy of moral worth by positioning waiting as something that can be done well or badly.

\section{Acknowledgements}

I thank all my interlocutors who made this research possible for their help and time. I am also grateful to my colleagues in the WAIT project, and particularly Christine M. Jacobsen, Shahram Khosravi and Kari Anne Drangsland, for providing valuable feedback on my chapter and insightful discussions on the concept of waiting. The chapter is based on research funded by the Norwegian Research Council through the programs VAM ('Provision of Welfare to Irregular Migrants (PROVIR)'), and SAMKUL ('Waiting for Uncertain Futures: The Temporalities of Irregular Migrants (WAIT)').

\section{Notes}

1 All interlocutors' names are pseudonyms. Due to strong privacy concerns when doing research with irregular migrants, I have also in some cases chosen to alter what I considered non-essential information (i.e. country of origin, age, years in the country, etc.).

2 'Papirløs' is the main term used by NGOs in Norway for irregularised migrants from non-EU countries. The direct translation is 'paperless' or 'without paper,' however in the chapter I will mainly translate the term to 'undocumented,' as this is more commonly used in English.

3 Numbers are notoriously unreliable, but during the period of my study (20111018), NGOs working in the field estimated that there were between 3,000 and 5,000 rejected asylum seekers that had remained in the country for more than 5 years.

4 The political platform for the Norwegian Government, formed by the Conservative Party, the Progress Party, the Liberal Party and the Christian Democratic Party, 17 January 2019, proposes a one-time solution for older 'unreturnable' asylum seekers who have lived in Norway for more than 16 years.

5 In a few cases it was disputed which was their country of origin, and neither of the embassies in question was willing to grant papers when they were approached. These included, for example Eritreans born in Ethiopia and Iranian Kurdish refugees in Iraq. See also Brux et al. (2019).

6 See also Øien et al. (2011), Drevland et al. (2017), Brux et al. (2019) for similar observations.

7 Until 2004 and since 2011, rejected asylum seekers have been offered state accommodation in regular asylum reception centres. In 2012 and 2013, rejected asylum seekers constituted the largest group of people living in these centres. In 2013, 5,700 people with a so-called duty to leave (utreiseplikt) lived in reception centres, which constituted $35 \%$ of all residents. In 2017, this number had 
dropped to 1,421 persons, which constituted about $28 \%$ of all residents (UDI annual reports 2011-2017).

8 These include two limited on-off programs in 2004 and 2013 through which approximately 1,000 and 300 children and their families were regularised, respectively. To be eligible to apply, the child had to have stayed in Norway for more than three years. In 2007, Norway also implemented an ongoing regularisation mechanism, which was further strengthened in 2013. Through this, children, and their families, can be granted a residence permit on the grounds of strong humanitarian consideration on a case-by-case basis.

9 The police formally charged PLOG AS and Viste in April 2019, and operations were suspended.

\section{References}

Adam, B. (2003). Reflexive modernization temporalized. Theory, Culture \& Society. 20 (2), 59-78. DOI: 10.1177/0263276403020002004.

Anderson, B., Gibney, M.J. \& Paoletti, E. (2011) Citizenship, deportation and the boundaries of belonging. Citizenship Studies. 15 (5), 547-563. DOI: 10.1080/13621025.2011.583787.

Bendixsen, S. (2013) Becoming members in the community of value: Ethiopian irregular migrants enacting citizenship in Norway. In: Edelstein, A. \& Dugan, M. (eds.) Migration matters. Oxfordshire, Inter-Disciplinary Press, pp. 3-22.

Berlant, L (2011) Cruel optimism. Durham, Duke University Press.

Brux, C., Hilden, P.K. \& Middelthon, A.O. (2019) 'Klokka tikker, tiden går': Time and irregular migration. Time \& Society. 28 (4), 1429-1463. DOI: 10.1177/ $0961463 X 18783356$.

Carling, J. \& Collins, F. (2018) Aspiration, desire and drivers of migration. Journal of Ethnic and Migration Studies. 44 (6), 909-926. DOI: 10.1080/1369183X.2017.1384134.

Chauvin, S. \& Garcés-Mascareñas, B. (2012) Beyond informal citizenship: The new moral economy of migrant illegality. International Political Sociology. 6 (3), 241-259. DOI: 10.1111/j.1749-5687.2012.00162.x.

De Genova, N. (2002) Migrant 'illegality' and deportability in everyday life. Annual Review of Anthropology. 31 (1), 419-447. DOI: 10.1146/annurev. anthro.31.040402.085432.

De Genova, N. (2013) Spectacles of migrant 'illegality': The scene of exclusion, the obscene of inclusion. Ethnic and Racial Studies. 36 (7), 1180-1198. DOI: 10.1080/01419870.2013.783710.

Drangsland, K.A.K. (2019) Waiting as a redemptive state: The 'Lampedusa in Hamburg'and the offer from the Hamburg government. Time \& Society. DOI: $10.1177 / 0961463 X 19890989$.

Drangsland, K.A. (2020) Mo's challenge. Waiting and the question of methodological nationalism. In C. M. Jacobsen, M.-A. Karlsen, \& S. Khosravi (eds.) Waiting and the Temporalities of Irregular Migration. London and New York: Routledge.

Drevland, W.H., Nårstad, S. \& Reme, M.A. (2017) Hvem skal holde meg i hånden når jeg dør? Eldre lengeværende flyktningkvinner på asylmottak. Report from RIA (Rettferdighet i Asylpolitikken). Available from: https://riarogaland.files. wordpress.com/2017/05/rapport_eldre-lengevc3a6rende_30-05-2017.pdf.

Feldman, I. (2015) Looking for humanitarian purpose: Endurance and the value of lives in a Palestinian refugee camp. Public culture. 27 (3 (77)), 427-447. DOI: $10.1215 / 08992363-2896171$. 
Ferguson, J. (2006) Global shadows: Africa in the neoliberal world order. Durham, Duke University Press.

Frosh, S. (2015) Endurance. American Imago. 72 (2), 157-175. Project MUSE. DOI: 10.1353/aim.2015.0009.

Haas, B.M. (2012) Suffering and the struggle for recognition: Lived experiences of the U.S. political asylum process. PhD Thesis, University of California, San Diego. Available from: http://escholarship.org/uc/item/7pd0w87k\#page-483.

Hage, G. (2009). Waiting out the crisis: On stuckedness and governmentality. In: Hage, G. (ed.) Waiting. Carlton Victoria, Melbourne University Publishing, pp. $97-106$.

Hernandez-Carretero, M. (2016) Hope and uncertainty in Senegalese migration to Spain: Taking chances on emigration but not upon return. In: Kleist, N. \& Thorsen, D. (eds.) Hope and uncertainty in contemporary African migration. London and New York, Routledge, pp. 127-147.

Karlsen, M.A. (2017) The limits of egalitarianism: Irregular migration and the Norwegian welfare state. In: Bendixsen, S., Bringslid, M.B. \& Vike, H. (eds.) Egalitarianism in Scandinavia. Historical and contemporary perspectives. London, Palgrave Macmillan, pp. 223-243.

Karlsen, M.A. (forthcoming) Precarious inclusion. Migration control and access to welfare in Norway. Series on edge: Ethnographies and theories of threshold phenomena. London and New York, Routledge.

Kleist, N. \& Jansen, S. (2016) Introduction: Hope over time-Crisis, immobility and future-making. History and Anthropology. 27 (4), 373-392. DOI: 10.1080/02757206.2016.1207636.

Lahad, K. (2017) A table for one: A critical reading of singlehood, gender and time. Manchester, Manchester University Press.

Lønseth, P.K. (2011) Returnekternes ansvar. Aftenposten, kronikk [Online]. 24 October. Available from: http://www.aftenposten.no/meninger/Returnekternesansvar-6677873.html\#.UxzCl_1_vyA. [accessed 16 May 2015].

Machinya, J. (2020) Migration control, temporal irregularity and waiting: Undocumented Zimbabwean migrants' experiences of deportability in South Africa. In C. M. Jacobsen, M.-A. Karlsen, \& S. Khosravi (eds.) Waiting and the Temporalities of Irregular Migration. London and New York: Routledge.

Mains, D. (2007) Neoliberal times: Progress, boredom, and shame among young men in urban Ethiopia. American Ethnologist. 34 (4), 659-673. DOI: 10.1525/ ae.2007.34.4.659.

Mburu, C.B., Middelthon, A.L. \& Hilden, P.K. (2015) Utvikling av psykiske og psykososiale helsetjenester ved helsesenteret for papirløse migranter. In: Bendixsen, S.K., Jacobsen, C.M. \& Søvig, K.H. (eds.) Eksepsjonell velferd? Irregulare migranter i det norske velferdssamfunnet. Oslo, Gyldendal Norsk Forlag, pp. 163-180.

Neale, T. (2012) Enduring abandonment. Postcolonial Studies. 15 (3), 399-402. DOI: 10.1080/13688790.2012.753665.

Ottesen, S.H., Eick, F. \& Hilden, P.K. (2015) Erfaringer fra helsesenteret for papirløse migranter. In: Bendixsen, S.K., Jacobsen, C.M. \& Søvig, K.H. (eds.) Eksepsjonell velferd? Irregulare migranter i det norske velferdssamfunnet. Oslo, Gyldendal Norsk Forlag, pp. 144-162.

Pettit, H. \& Ruijtenberg, W. (2019) Migration as hope and depression: Existential im/mobilities in and beyond Egypt. Mobilities. 14 (5), 1-15. DOI: 10.1080/ 17450101.2019.1609193. 
Povinelli, E.A. (2011) Economies of abandonment: Social belonging and endurance in late liberalism. Durham, Duke University Press.

Ramsay, G. (2019) Time and the other in crisis: How anthropology makes its displaced object. Anthropological Theory. 1-29. DOI: 10.1177/1463499619840464.

Sharma, S. (2014) In the meantime: Temporality and cultural politics. Durham, Duke University Press.

Straughan, E., Bissell, D. \& Gorman-Murray, A. (2020) The politics of stuckness: Waiting lives in mobile worlds. Environment and Planning C: Politics and Space. 38 (4), 636-655. DOI: 10.1177/2399654419900189.

Van Houte, M. \& Leerkes, A. (2019) Dealing with (non-) deportability. A comparative policy analysis of the post-entry migration enforcement regimes of Western European countries. A Report commissioned by the 'Van Zwol committtee'. Maastricht, UNU-Merit.

Vigh, H. (2009) Motion squared: A second look at the concept of social navigation. Anthropological Theory. 9 (4), 419-438. DOI: 10.1177/1463499609356044.

Willen, S.S. (2007) Toward a critical phenomenology of 'illegality': State power, criminalization, and abjectivity among undocumented migrant workers in Tel Aviv, Israel. International Migration. 45 (3), 8-38. DOI: 10.1111/j.1468-2435.2007.00409.x.

Wool, Z.H. (2017) In-durable sociality: Precarious life in common and the temporal boundaries of the social. Social Text. 35 (1 (130)), 79-99. DOI: $10.1215 / 01642472-3728008$.

Øien, C. \& Sønsterudbråten, S. (2011) No way in, no way out? A study of living conditions of irregular migrants in Norway. Fafo-report 2011-03. Oslo. 